Canadian Science Publishing

Canadian Journal of Earth Sciences Revue canadienne des sciences de la Terre

\title{
Arctosaurus osborni, a Late Triassic archosauromorph reptile from the Canadian Arctic Archipelago
}

\begin{tabular}{|r|l|}
\hline Journal: & Canadian Journal of Earth Sciences \\
\hline Manuscript ID & cjes-2016-0159.R1 \\
\hline Manuscript Type: & Article \\
\hline Date Submitted by the Author: & 12-Oct-2016 \\
\hline Complete List of Authors: & Sues, Hans-Dieter; Smithsonian Institution, Paleobiology; \\
\hline Keyword: & Reptilia, Triassic, Nunavut \\
\hline & \\
\hline
\end{tabular}

\section{SCHOLARONE ${ }^{m}$ \\ Manuscripts}


Arctosaurus osborni, a Late Triassic archosauromorph reptile from the Canadian Arctic Archipelago

Hans-Dieter Sues

H.-D. Sues. Department of Paleobiology, National Museum of Natural History, Smithsonian Institution, MRC 121, P.O. Box 37012, Washington, DC 20013-7012, U.S.A. suesh@si.edu

\begin{abstract}
Arctosaurus osborni is known only from an incomplete cervical vertebra from the Upper Triassic Heiberg Formation of Cameron Island, Nunavut, Canada. Re-examination of the unique specimen indicates that it represents an archosauromorph reptile, possibly from the clade Allokotosauria. To date, Arctosaurus osborni represents the sole record of Late Triassic continental tetrapods from Nunavut and the northernmost record of such animals anywhere in the world.
\end{abstract}

Résumé: Arctosaurus osborni est connu seulement d'une vertèbre cervicale incomplète provenant de la Formation Heiberg du Trias supérieur de l'île Cameron, Nunavut, Canada. Révision de l'exemplaire unique indique qu'il représente un reptile archosauromorphe, peut-être de le groupe Allokotosauria. À ce jour, Arctosaurus osborni représente le seul record des tétrapodes continentaux du Trias supérieur du Nunavut et le record du plus septentrional de ces animaux partout dans le monde. 
Key words: Reptilia - Triassic - Nunavut

\section{Introduction}

The vast territories of the Canadian Arctic Archipelago have yielded very few remains of Mesozoic continental vertebrates to date. Although potentially fossiliferous strata are extensively exposed, exploration has been limited due to the logistical challenges of working in such remote and difficult terrain. There have been brief reports of fragmentary skeletal remains of Late Cretaceous dinosaurs from Nunavut, specifically Axel Heiberg Island (Vavrek et al. 2014) and Bylot Island (Larsson et al. 2007). In addition, Tarduno et al. (1998) announced the discovery of an assemblage comprising champsosaurid reptiles, turtles, and fishes from the Upper Cretaceous (Turonian-Coniacian) Kanguk Formation of Axel Heiberg Island.

By contrast, virtually nothing is known about continental vertebrates from the Triassic and Jurassic strata of Nunavut. Ash and Basinger (1991) and Vavrek et al. (2007) reported on several occurrences of Late Triassic plants from Axel Heiberg, Cameron, Cornwall, and Ellesmere islands. The single published record of a continental vertebrate fossil to date is an incomplete cervical vertebra of a reptile from the Triassic-Jurassic Heiberg Formation of Cameron Island. Adams (1875) first described this fossil and designated it as the holotype of a new genus and species, Arctosaurus osborni. The famous Arctic explorer Sherard Osborn collected the specimen during the search for Sir John Franklin's lost expedition (M'Clintock 1859).

In view of the incomplete nature of its holotype and only known specimen, it is not surprising that the phylogenetic position of Arctosaurus osborni has remained uncertain ever since its initial description. When Adams (1875) received the fossil for study it had been identified as a teleosaur, a member of a group of mostly marine crocodyliform reptiles from the 
Jurassic and Early Cretaceous. Adams rejected this assessment based on various morphological differences and, in the absence of comparable material, identified the vertebra merely as “saurian”. Lydekker (1889, pp. 352-353) examined the holotype of Arctosaurus osborni and considered it dinosaurian, "more or less closely allied" to Anchisauridae, a group of Early Jurassic sauropodomorphs. Huene (1902) referred Arctosaurus osborni to turtles. It is important to note that this assignment was not based on comparisons with undisputed turtles but rather on similarities to allegedly chelonian vertebrae from the Middle Triassic of Germany, which Huene (1902) named Chelyzoon. Wild (1973) later reidentified these vertebrae as belonging to the archosauromorph reptile Tanystropheus conspicuus. Two major synoptic overviews of reptilian classification (Huene 1956; Romer 1966) placed Arctosaurus osborni with a question mark among sauropodomorph ("prosauropod") dinosaurs. In a revision of the sauropodomorph Anchisaurus capensis and related taxa, Galton and Cluver (1976) illustrated and commented on the holotype of Arctosaurus osborni and tentatively assigned it to theropod dinosaurs. It should be noted that their drawings (Galton and Cluver 1976, fig. 13A-E) represent partial reconstructions rather than the actual specimen. Russell (1984) cited the late Donald Baird as suggesting trilophosaurid affinities for Arctosaurus osborni but provided no evidence for this assessment. Finally, Nesbitt et al. (2007) noted that the allegedly dinosaurian features of Arctosaurus osborni have a wider phylogenetic distribution among Archosauriformes (the clade comprising Archosauria and their closest relatives) and considered this species an indeterminate archosauriform.

This paper provides a new illustrated description of the holotype of Arctosaurus osborni and reviews its possible relationships. Recognizing that the dark color of the fossil makes it challenging to photograph, the vertebra also was scanned using a Faro Edge ScanArm HD. The scanning data were collected and processed in Geomagic Studio. 


\section{Systematic paleontology}

Reptilia Laurenti, 1768

Diapsida Osborn, 1903 sensu Benton, 1985

Archosauromorpha Huene, 1946 sensu Benton, 1985

Arctosaurus osborni Adams, 1875

HOLOTYPE: National Museum of Ireland - Natural History NMING:F14878, an incomplete cervical vertebra.

HORIZON AND LOCALITY: Adams (1875) cited a paper by Haughton (1860, p. 210) who wrote (in section "IV. - The Lias Rocks."), "Captain Sherard Osborn also found broken vertebrae of a Teleosaurus, 150 feet up Rendezvous Hill, Byam Martin Channel, at the north-west extremity of Bathurst Island; they were certainly in situ.” A slightly different version of Haughton's paper (where the vertebrae were identified as those of "an Ichthyosaurus") had earlier been published as Appendix IV to M'Clintock (1859). Adams (1875) reported only on one vertebra, which is now housed in the National Museum of Ireland - Natural History in Dublin. This specimen had been given to John William Salter, a noted British paleontologist, who in due course presented it to Dr. Alexander Carte, curator of the Royal Dublin Society. The Society's entire collection was transferred to the Museum of Science \& Art, Dublin, the precursor of the present-day museum. There is no extant record when the specimen was acquired (N.T. Monaghan, personal communication, 2016). 
While no additional detail concerning the type locality is available, the holotype of Arctosaurus osborni was collected at the northwestern corner of Cameron Island, which itself is located at the northwestern extremity of Bathurst Island (latitude $76^{\circ} 30^{\prime} \mathrm{N}$, longitude $103^{\circ} 51^{\prime} \mathrm{W}$ ) and was formally named only in 1952. The fossil probably derived from strata of the Heiberg Formation, which forms a sandstone-dominated unit in the Sverdrup Basin and is considered Late Triassic (Norian) to Early Jurassic (Pliensbachian) in age (Embry 1983). Embry (1983) divided the Heiberg Formation into three members (in ascending order): Romulus, Fosheim, and Remus. The strata of the Romulus and Fosheim members represent the progradation of a major deltaic complex into the Sverdrup Basin during Norian to Sinemurian times, which were followed by destruction of the delta and a marine transgression commencing in the Pliensbachian (based on ammonoids) and represented by the strata of the Remus Member (Embry 1983). Plant macrofossils support a Late Triassic date for the Fosheim Member (Ash and Basinger 1991; Vavrek et al. 2007). Tozer (1963, p. 645) claimed that the reptilian fossil(s) collected by Osborn came from the overlying Jaeger Formation, which is marine in origin and Jurassic in age. However, Tozer presented no evidence for this assertion. The holotype of Arctosaurus osborni is clearly not referable to any of the known groups of Jurassic marine reptiles and, for that reason, is considered to be from the Upper Triassic portion of the Heiberg Formation.

DIAGNOSIS: Arctosaurus osborni is distinguished from other currently known archosauromorph reptiles by the presence of a deep arcuate groove on the ventrolateral surface of the centrum and the presence of a in posterior view somewhat V-shaped transpostzygapophyseal lamina.

DESCRIPTION: The vertebra NMING:F14878 (Figs. 2-3) is incomplete and somewhat crushed. Its neural spine and right prezygapophysis are broken off at their bases. The left side of the centrum has been almost completely obliterated and the posteroventral end of the left side of the 
neural arch is incomplete, including partial loss of the postzygapophysis. On the right side of the centrum, the regions of the diapophysis and parapophysis have been damaged. The surface texture in some areas suggests that the fossil was exposed for some time prior to discovery. Adams (1875, p. 159) considered the vertebra a "middle" cervical. Comparisons with cervical vertebrae of various archosauromorph reptiles confirm the identification of NMING:F14878 as a postaxial cervical, probably closer to the middle of that series based on the medial inclination of the prezygapophyseal facet.

In lateral view, the centrum of NMING:F14878 is more or less parallelogram-shaped, taller dorsoventrally than wide transversely at its anterior end, and twice as long anteroposteriorly than tall anteriorly (Fig. 2A). Its greatest anteroposterior length is $34 \mathrm{~mm}$, comparable in length to the centra of the mid-cervical vertebrae of Trilophosaurus buettneri (Gregory 1945). Both articular ends of the centrum are poorly preserved. The anterior articular surface is definitely and the more incomplete posterior surface is probably concave. By contrast, the cervical centra of Trilophosaurus buettneri are procoelous (Spielmann et al. 2008). The anterior articular end is positioned dorsal to the posterior one, as in various non-archosaurian archosauromorphs (e.g., Trilophosaurus buettneri; Gregory 1945), pseudosuchians (e.g., Arizonasaurus babbitti; Nesbitt 2005), and certain theropod dinosaurs (e.g., Coelophysis bauri; Colbert 1989). In lateral view, the ventral margin of the centrum arches anteriorly. The ventral surface of the centrum bears a distinct median keel (Fig. 2F).

There is no trace of a neurocentral suture between the centrum and the neural arch. The anteroposterior length of the transversely narrow neural arch is $49 \mathrm{~mm}$. The prezygapophysis extends anterior well beyond the anterior end of the centrum. Its articular facet faces dorsomedially at an angle of about $45^{\circ}$ to the horizontal plane and has a long axis that extends anterodorsally and laterally. The neural spine surmounts the posterior half of the neural arch and, 
although broken close to its base, was apparently canted anterodorsally. Its base has a distinct, largely dorsally facing fossa between the pre- and postzygapophyses on either side of the neural arch (Fig. 3B). In transverse section, the neural spine has a subtriangular outline, narrowing anteriorly. It bifurcates posteriorly, forming a deep and wide interspinous recess between the postzygapophyses with a narrow median groove for interspinuous ligaments and an extensive ventral bony floor. The in posterior view slightly V-shaped transpostzygapophyseal lamina (sensu Spielmann et al. 2009) between the postzygapophyses (Fig. 3C) is continuous anteriorly with the dorsal roof of the neural canal. It differs from the horizontal transpostzygapophyseal lamina between the postzygapophyses in Tanystropheus conspicuus (Wild 1973) and Trilophosaurus spp. (Spielmann et al. 2008). Furthermore, the well-developed transzygapophyseal lamina in the latter and in Spinosuchus caseanus has a median cleft (Spielmann et al. 2008, 2009) whereas the lamina is only weakly embayed posteriorly in NMING:F14878. The anterior edge of the neural spine bears a slit-like groove for the interspinuous ligaments that terminates ventrally in a deep recess between the prezygapophyses. The long bony floor between the latter is largely broken. The spinoprezygapophyseal lamina curves anteriorly from the anterolateral corner of the base of the neural spine.

A small epipophysis surmounts the postzygapophysis (Figs. 2A, 3), as in certain nonarchosaurian archosauromorphs such as Teraterpeton hrynewichorum (Sues 2003), Mesosuchus browni (Nesbitt 2011), and Azendohsaurus madagaskarensis (Nesbitt et al. 2015), and in various pseudosuchians and dinosaurs (Nesbitt 2011). It is posteriorly pointed but does not extend posteriorly beyond the articular facet of the postzygapophysis, as in Azendohsaurus madagaskarensis (Nesbitt et al. 2015) and Teraterpeton hrynewichorum (Sues 2003) but unlike in Tanystropheus conspicuus (Wild 1973). The postzygapophyseal facet faces almost directly 
ventrally with only a slight posterolateral inclination. A small round depression just anteroventral to this facet received the tip of the prezygapophysis of the succeeding vertebra.

The parapophysis was located at the anteroventral corner of the centrum but no detail is evident due to damage in this region. The posterior centrodiapophyseal ridge arcs posterodorsally from the damaged region of the diapophysis and extends almost to the posterior end along the ventrolateral surface of the centrum. It overhangs a deep arcuate groove in the lateral surface of the centrum (Figs. 2A, 3A), as in the archosauromorph Azendohsaurus madagaskarensis (Nesbitt et al. 2015) and in the pseudosuchian Arizonasaurus babbitti (Nesbitt 2005). This groove does not open into the interior of the centrum. Its depth was possibly slightly accentuated by smallscale fracturing of the bone. Galton and Cluver (1976) identified the groove as a pleurocoel but Nesbitt et al. (2007) noted that it is not homologous to the pneumatic openings in the vertebrae of many saurischian dinosaurs. The diapophysis was located at about mid-height on the lateral surface of the centrum near its anterior end. The postzygadiapophyseal lamina is distinct posteriorly but fades into the lateral surface of the neural arch more anteriorly. The spinoprezygapophyseal lamina curves anteriorly from the anterolateral corner of the base of the neural spine to the anterior end of the prezygapophyseal facet.

\section{Discussion}

Re-examination of the holotype of Arctosaurus osborni demonstrates that it belongs to a non-archosaurian archosauromorph, not a dinosaur. Referral to Archosauromorpha is supported by three features (Ezcurra et al. 2014): the (in lateral view) parallelogram-shaped centrum, the anterior articular surface of which is set dorsal to the posterior one; the well-developed posterior centrodiapophyseal ridge; and the positioning of the zygapophyses close to each other medially. In addition, NMING:F14878 has two features that Nesbitt et al. (2015) hypothesized as shared 
derived character-states for the archosauromorph clade Allokotosauria: the apparently anterodorsally canted neural spine (character-state 116-1; Nesbitt et al. 2015) and the posteriorly pointed epipophyses on the dorsal surface of the postzygapophyses (character-state 119-1; Nesbitt et al. 2015). Allokotosauria comprises a variety of Triassic non-archosaurian archosauromorphs, most of which developed dental specializations indicative of omnivory or herbivory, and is currently definitely known from the Late Triassic of North America, Madagascar, Morocco, and possibly India (Nesbitt et al. 2015). If indeed referable to Allokotosauria, Arctosaurus osborni would greatly extend the known paleogeographic distribution of this clade.

Arctosaurus osborni appears to be distinguished from other currently known archosauromorph reptiles by the deep arcuate groove dorsally bounded by the posterior centrodiapophyseal ridge on the ventrolateral surface of the centrum and the in posterior view slightly V-shaped transpostzygapophyseal lamina. It represents the northernmost occurrence of a Late Triassic land-dwelling tetrapod discovered to date. Interestingly, the richly fossiliferous Upper Triassic continental strata of the Fleming Fjord Formation of central East Greenland (between latitudes $71^{\circ} 15^{\prime} \mathrm{N}$ and $71^{\circ} 50^{\prime} \mathrm{N}$ ) have not yet yielded skeletal remains of nonarchosaurian archosauromorphs (Clemmensen et al. 2016). Arctosaurus osborni underscores the potential for future paleontological exploration of the Upper Triassic continental rocks in the Canadian Arctic Archipelago.

\section{Acknowledgements}

I am greatly indebted to Nigel T. Monaghan, Keeper of Natural History, National Museum of Ireland - Natural History (Dublin) for the loan of the holotype of Arctosaurus osborni. I also thank Steven J. Jabo for photographing the specimen and Holly E. Little for surface- 
scanning it. An anonymous reviewer and Associate Editor James D. Gardner provided helpful comments on a draft of the manuscript.

\section{References}

Adams, A.L. 1875. On a fossil saurian vertebra, Arctosaurus osborni, from the Arctic regions. Proceedings of the Royal Irish Academy, 2: 177-179.

Ash, S.R., and Basinger, J.F. 1991. A high latitude Upper Triassic flora from the Heiberg Formation, Sverdrup Basin, Arctic Archipelago. Geological Survey of Canada, Bulletin, 412: 101-131.

Benton, M.J. 1985. Classification and phylogeny of the diapsid reptiles. Zoological Journal of the Linnean Society, 84: 97-164.

Clemmensen, L.B., Milàn, J., Adolfssen, J.S., Estrup, E.J., Frobøse, N., Klein, N., Mateus, O., and Wings, O. 2016. The vertebrate-bearing Late Triassic Fleming Fjord Formation of central East Greenland revisited: stratigraphy, palaeoclimate and new palaeontological data. In Mesozoic biotas of Scandinavia and its Arctic territories. Edited by B.P. Kear, J. Lindgren, J.H. Hurum, J. Milàn, and V. Vajda. Geological Society, London, Special Publications, 434, pp. 31-47. doi: 10.1144/SP434.3

Colbert, E.H. 1989. The Triassic dinosaur Coelophysis. Museum of Northern Arizona Bulletin, 57, pp. $1-160$.

Embry, A.F. 1983. Stratigraphic subdivision of the Heiberg Formation, eastern and central Sverdrup Basin, Arctic Islands. In Current Research, Part B. Geological Survey of Canada, Paper 83-1B, pp. 205-213. 
Ezcurra, M.D., Scheyer, T.M., and Butler, R.J. 2014. The origin and early evolution of Sauria: reassessing the Permian saurian fossil record and the timing of the crocodile-lizard divergence. PLoS ONE 9(2): e89165. doi: 10.1371/journal.pone.0089165

Galton, P.M., and Cluver, M.A. 1976. Anchisaurus capensis (Broom) and a revision of the Anchisauridae (Reptilia, Saurischia). Annals of the South African Museum, 69: 121-159.

Gregory, J.T. 1945. Osteology and relationships of Trilophosaurus. University of Texas Special Publication, 4401: 273-359.

Haughton, S. 1860. Geological account of the Arctic Archipelago, drawn up from specimens collected by Captain F. L. M'Clintock, R.N., from 1849 to 1859. Journal of the Geological Society of Dublin, 8: 196-213.

Huene, F. 1902. Übersicht über die Reptilien der Trias. Geologische und Paläontologische Abhandlungen, Neue Folge, 8: 97-156.

Huene, F. 1946. Die grossen Stämme der Tetrapoden in den geologischen Zeiten. Biologisches Zentralblatt, 65: 268-275.

Huene, F. 1956. Paläontologie und Phylogenie der niederen Tetrapoden. Gustav Fischer Verlag, Jena. 716 pp.

Larsson, H.C.E., de Boef, M., Dececchi, T.A., Harrison, L., Rybczynski, N., and Wilson, L. 2007. Insight into the Cenomanian (Late Cretaceous) terrestrial and marine vertebrate fauna of Bylot Island, Nunavut. In Canadian Palaeontology Conference proceedings no. 5, St. John's, Nfld., 20-23 September 2007. Edited by D. McIlroy. Geological Association of Canada, Palaeontology Division, St. John's, Nfld. p. 16.

Laurenti, J.N. 1768. Specimen medicum, exhibens synopsin reptilium emendatam cum experimentis circa venena et antidota reptilium Austriacorum. J.T. de Trattern, Vienna. 214 pp. 
Lydekker, R. 1889. Notes on new and other dinosaurian remains. Geological Magazine, Decade 3, 6: $352-355$.

M'Clintock, Captain [F.L.]. 1859. The voyage of the 'Fox' in the Arctic seas. A narrative on the discovery of the fate of Sir John Franklin and his companions. John Murray, London. 403 pp.

Nesbitt, S.J. 2005. Osteology of the Middle Triassic pseudosuchian archosaur Arizonasaurus babbitti. Historical Biology, 17: 19-47. doi: 10.1080/08912960500476499.

Nesbitt, S.J. 2011. The early evolution of archosaurs: relationships and the origin of major clades. Bulletin of the American Museum of Natural History, 352: 1-292. doi: 10.1206/352.1

Nesbitt, S.J., Irmis, R.B., and Parker, W.G. 2007. A critical re-evaluation of the Late Triassic dinosaur taxa of North America. Journal of Systematic Palaeontology, 5: 209-243. doi: $10.1017 / \mathrm{S} 1477201907002040$

Nesbitt, S.J., Flynn, J.J., Pritchard, A.C., Parrish, J.M., Ranivoharimanana, L., and Wyss, A.R. 2015. Postcranial osteology of Azendohsaurus madagaskarensis (?Middle to Upper Triassic, Isalo Group, Madagascar) and its systematic position among stem archosaur reptiles. Bulletin of the American Museum of Natural History, 398: 1-126. doi: 10.1206/amnb-899-00-1-126.1

Osborn, H.F. 1903. The reptilian subclasses Diapsida and Synapsida and the early history of the Diaptosauria. Memoirs of the American Museum of Natural History, 1: 449-507.

Romer, A.S. 1966. Vertebrate paleontology. Third edition. The University of Chicago Press, Chicago. 468 pp.

Russell, D.A. 1984. A check list of the families and genera of North American dinosaurs. Syllogeus, 53: 1-35. 
Spielmann, J.A., Lucas, S.G., Rinehart, L.F., and Heckert, A.B. 2008. The Late Triassic archosauromorph Trilophosaurus. New Mexico Museum of Natural History \& Science Bulletin, 43: 1-177.

Spielmann, J.A., Lucas, S.G., Heckert, A.B., Rinehart, L.F., and Richards, H.R. III. 2009. Redescription of Spinosuchus caseanus (Archosauromorpha: Trilophosauridae) from the Upper Triassic of North America. Palaeodiversity, 2: 283-313.

Sues, H.-D. 2003. An unusual new archosauromorph reptile from the Upper Triassic Wolfville Formation of Nova Scotia. Canadian Journal of Earth Sciences, 40: 635-649. doi: 10.1139/E02-048

Tarduno, J.A., Brinkman, D.B., Renne, P.R., Cottrell, R.D., Scher, H., and Castillo, P. 1998. Evidence for extreme climatic warmth from Late Cretaceous Arctic vertebrates. Science, 282: 2241-2243. doi: 10.1126/science.282.5397.2241

Tozer, E.T. 1963. Northwestern Cameron Island. In Geology of the north-central part of the Arctic Archipelago, Northwest Territories (Operation Franklin). By Y.O. Fortier, R.G. Blackadar, B.F. Glenister, H.R. Greiner, D.J. McLaren, N.J. McMillan, A.W. Norris, E.F. Roots, J.G. Souther, R. Thorsteinsson, and E.T. Tozer. Geological Survey of Canada Memoir, 320. pp. 639-645.

Vavrek, M.J., Hills, L.V., and Currie, P.J. 2014. A hadrosaurid dinosaur (Dinosauria: Ornithischia) from the Late Cretaceous (Campanian) Kanguk Formation of Axel Heiberg Island, Nunavut, Canada, and its ecological and geographical implications. Arctic, 67, 1-9. Vavrek, M.J., Larsson, H.C.E., and Rybczynski, N. 2007. A Late Triassic flora from east-central Axel Heiberg Island, Nunavut, Canada. Canadian Journal of Earth Sciences, 44: 1653-1659. doi:10.1139/E07-042 
Wild, R. 1973. Die Triasfauna der Tessiner Kalkalpen. XXIII. Tanystropheus longobardicus (Bassani) (Neue Ergebnisse). Schweizerische Paläontologische Abhandlungen, 95: 1-162.

Figure legends

Fig. 1. (A) Map of Nunavut, Canada, with Bathurst Island highlighted in black. (B) Map of Bathurst Island with Cameron Island and (boxed) the general area where the holotype of Arctosaurus osborni was found. (C) Simplified geological map of the northwestern corner of Cameron Island with Rendezvous Hill. Modified from Tozer (1963).

Fig. 2. Cervical vertebra of Arctosaurus osborni, NMING:F14878 (holotype). Photographs of the specimen in (A) right lateral, (B) left lateral, (C) posterior, (D) anterior, (E) dorsal, and (F) ventral views. Scale bar equals $1 \mathrm{~cm}$. Abbreviation: $\mathrm{k}$, median keel on ventral surface of centrum.

Fig. 3. Cervical vertebra of Arctosaurus osborni, NMING:F14878 (holotype). Surface renderings of the vertebra in (A) right lateral, $(\mathrm{B})$ dorsal, and $(\mathrm{C})$ posterior views. Length of vertebral centrum: $34 \mathrm{~mm}$. Abbreviations: cdl, posterior centrodiapophyseal lamina; d, lateral depression at base of neural spine; ep, epipophysis; fo, fossa for reception of prezygapophysis; gr, ventrolateral groove; nc, neural canal; ns, neural spine; poz, postzgapophysis; prz, prezygapophysis; tpl, transzygapophyseal lamina. 


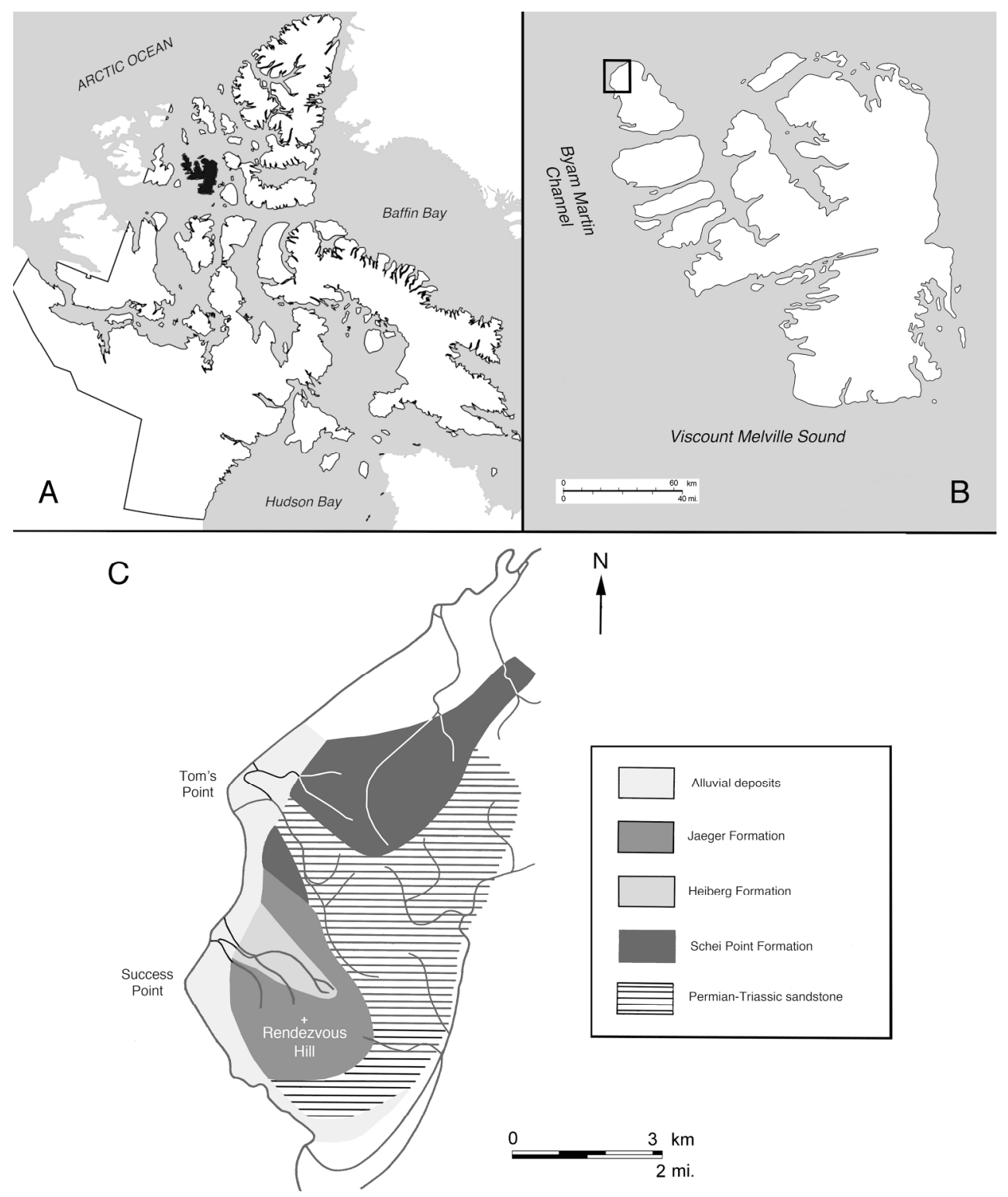

(A) Map of Nunavut, Canada, with Bathurst Island highlighted in black. (B) Map of Bathurst Island with Cameron Island and (boxed) the northwestern corner of the latter island where the holotype of Arctosaurus osborni was found. (C) Simplified geological map of the northwestern corner of Cameron Island with Rendezvous Hill. Modified from Tozer (1963).

$219 \times 269 \mathrm{~mm}(300 \times 300 \mathrm{DPI})$ 
A
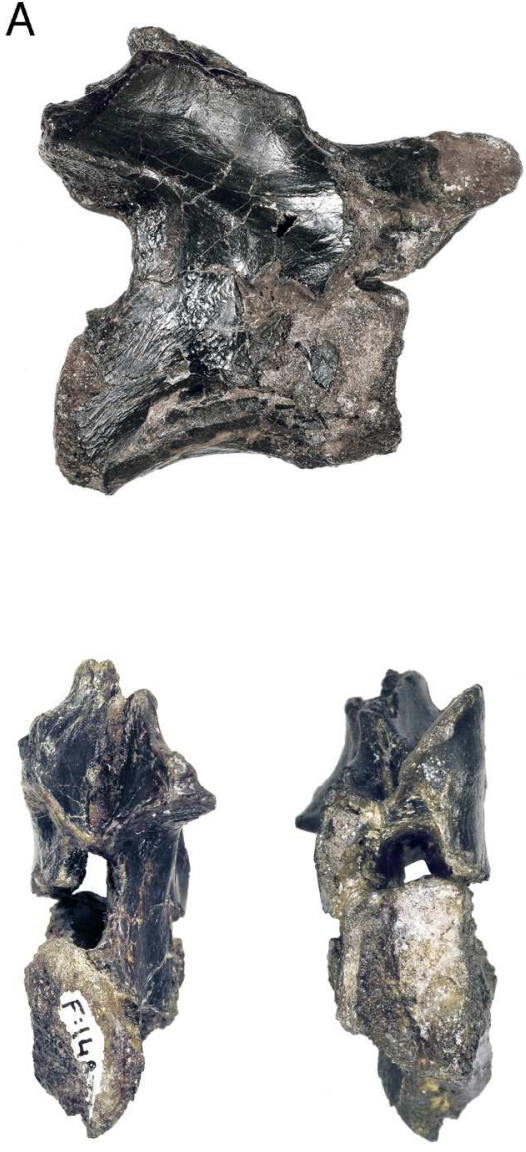

$\mathrm{C}$

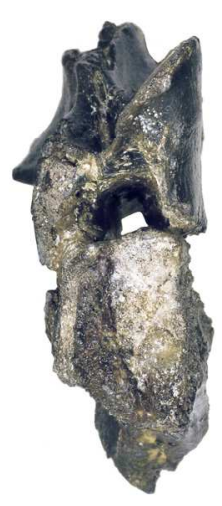

$\mathrm{D}$
$1 \mathrm{~cm}$

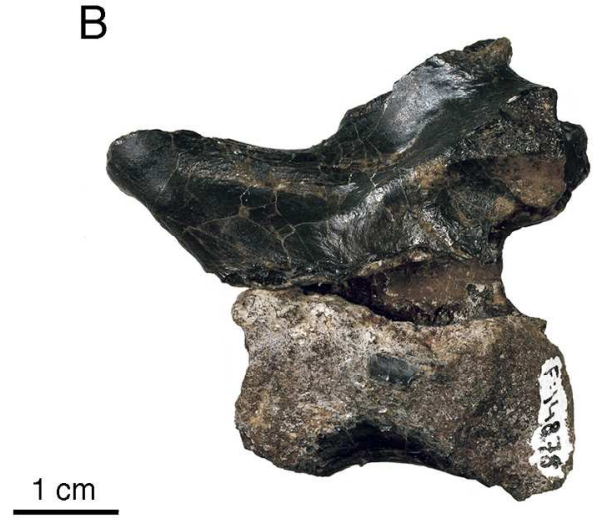

E
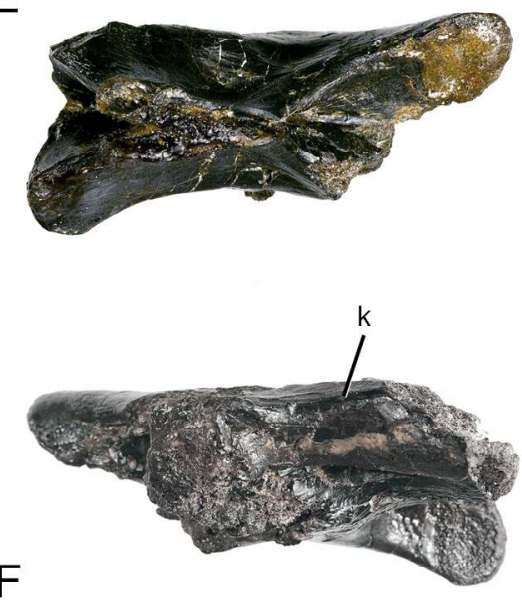

Cervical vertebra of Arctosaurus osborni, NMING:F14878 (holotype). Photographs of the specimen in (A) right lateral, (B) left lateral, (C) posterior, (D) anterior, (E) dorsal, and (F) ventral views. Scale bar equals 1 $\mathrm{cm}$. Abbreviation: $\mathrm{k}$, ventral keel.

$180 \times 190 \mathrm{~mm}(300 \times 300 \mathrm{DPI})$ 

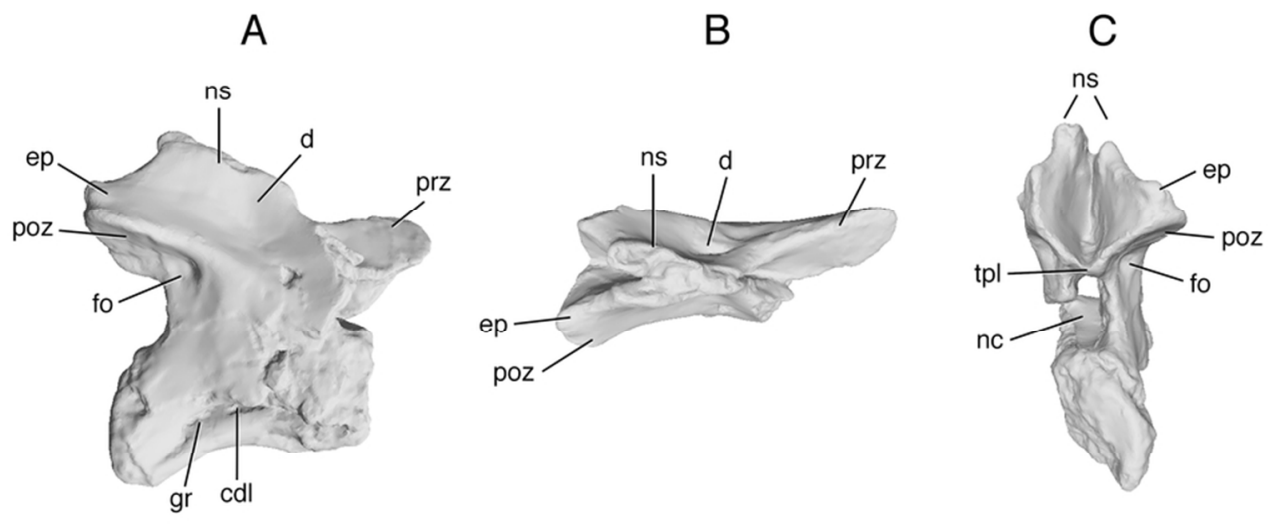

$82 \times 38 \mathrm{~mm}(300 \times 300$ DPI $)$ 